\title{
CLUSTERING AKSES AIR BERSIH DAN SANITASI LAYAK KABUPATEN/KOTA DI PROVINSI LAMPUNG
}

\author{
(Clustering of Clean Water access and Worth Sanitation in District/City Lampung Province)
}

\author{
Tri Rena Mayasari \\ Fungsional Statistisi Pertama BPS Kabupaten Pesawaran \\ Jalan Jend. Ahmad Yani no 119 Gedung Tataan, Pesawaran Lampung \\ Email: Tri.mayasari@bps.go.id
}

\begin{abstract}
ABSTRAK
Menjamin ketersediaan dan manajemen air dan sanitasi yang berkelanjutan untuk semua merupakan tujuan keenam dari Sustainable Development Goals (SDGS). Untuk mendorong tujuan tersebut, Provinsi Lampung menargetkan di tahun 2019 seluruh Kabupaten/Kota di Provinsi Lampung meraih 100 persen universal akses air dan sanitasi. Namun, pada kenyataannya, Provinsi Lampung berada pada segmen empat terbawah se-Nasional dalam hal akses air minum dan sanitasi layak. Rendahnya akses air minum dan sanitasi tersebut, merupakan dampak ketimpangan dan kesenjangan daerah di Provinsi Lampung. Adanya gap yang besar antara daerah Kota dan Kabupaten. Oleh karena itu, perlu adanya pengkajian analisis cluster untuk dijadikan landasan dalam pengambilan keputusan oleh Pemerintah Provinsi Lampung. Tujuan penelitian ini adalah untuk membahas kondisi air minum dan sanitasi layak di Provinsi Lampung dan untuk menganalisis Kabupaten/Kota mana yang perlu dipercepat dalam program agenda daerah 100 persen akses universal air minum dan sanitasi layak. Analisis yang digunakan pada penelitian ini adalah analisis deskriptif dan analisis cluster (analisis gerombol) dengan menggunakan metode Hierarchical Cluster. Hasil penelitian menunjukkan bahwa terdapat gap atau jarak antara daerah Perkotaan dan Pedesaan dalam hal akses air maupun sanitasi layak. Sedangkan analisis cluster menunjukkan bahwa dari 15 Kabupaten/Kota yang ada di Provinsi Lampung, terdapat 3 cluster/kelompok dengan karakteristik yang berbeda, yaitu daerah yang akses air dan sanitasi layak dengan kategori tinggi, sedang dan rendah. Cluster pertama (kategori tinggi) terdiri dari Kota Bandar Lampung dan Metro, Kabupaten Pringsewu dan Lampung Selatan, cluster kedua (Kategori Rendah) terdiri dari Kabupaten Way Kanan, Tulang Bawang Barat, Lampung Timur, Lampung Tengah dan Lampung Utara. Sedangkan cluster ketiga (Kategori sedang) terdiri dari Kabupaten Tulang Bawang, Pesawaran, Lampung Barat, Pesisir Barat, Mesuji dan Tanggamus. Dari hasil analisis ini, Pemerintah Provinsi Lampung disarankan untuk menyusun kebijakan yang mengarah pada perbaikan akses air dan sanitasi khususnya pada daerah di cluster kedua dan cluster ketiga.
\end{abstract}

Kata Kunci : air bersih, sanitasi layak, analisis cluster

\section{ABSTRACT}

Ensuring the availability and management of sustainable water and sanitation for all is the sixth goal of the Sustainable Development Goals (SDGs). To encourage this goal, Lampung Province targets in 2019 all Regencies / Cities in Lampung Province to achieve 100 percent universal access to water and sanitation. However, in reality, Lampung Province is in the lowest fourth segment in the nation in terms of access to drinking water and proper sanitation. The low access to drinking water and sanitation is the impact of regional inequality and disparity in Lampung Province. There is a large gap between the City and Regency areas. Therefore, it is necessary to have a cluster analysis study to be used as a basis for decision making by the Lampung Provincial Government. The purpose of this study is to discuss the condition of drinking water and proper sanitation in Lampung Province and to analyze which districts / cities need to be accelerated in the regional agenda program 100 percent universal access to drinking water and proper sanitation. The analysis used in this research is descriptive analysis and cluster analysis (cluster analysis) using the Hierarchical Cluster method. The results showed that there was a gap or distance between the City and Regency areas in terms of access to water and proper sanitation. While the cluster analysis shows that from 15 regencies / cities in Lampung Province, there are 3 clusters / groups with different characteristics, namely areas that have access to proper water and sanitation with high, medium and low categories. The first cluster (high category) consists of Bandar Lampung and Metro City, Pringsewu and South Lampung Regencies, the second cluster (Low Category) consists of Way Kanan, Tulang Bawang Barat, East Lampung, Central Lampung and North Lampung Regencies. While the third cluster (medium category) consists of Tulang Bawang, Pesawaran, West Lampung, Pesisir Barat, Mesuji and Tanggamus Regencies. From the results of this analysis, the Government of Lampung Province is advised to formulate policies that lead to improving access to water and sanitation, especially in areas in the second and third clusters.

Keywords: clean water, proper sanitation, cluster analysis 


\section{PENDAHULUAN}

Tujuan keenam dari Sustainable Development Goals (SDGs) adalah menjamin ketersediaan dan manajemen air serta sanitasi yang berkelanjutan untuk semua. Adanya komitmen SDGs ini, meluncurkan agenda nasional yaitu $100 \%$ akses universal air minum dan sanitasi yang tertuang dalam Rencana Pembangunan Jangka Menengah Nasional (RPJMN) 2015-2019. Tak terkecuali untuk Provinsi Lampung yang juga menargetkan seluruh Kabupaten/Kota di Lampung meraih 100\% universal air minum dan akses sanitasi layak pada tahun 2019.

Akses air minum layak (berkualitas) adalah air minum yang terlindung meliputi air ledeng (keran), keran umum, hydrant umum, terminal air, penampungan air hujan (PAH) atau mata air dan sumur terlindung, sumur bor atau sumur pompa, yang jaraknya minimal dari pembuangan kotoran, penampungan limbah dan pembuangan sampah (sirusa BPS). Sedangkan sanitasi layak adalah fasilitas sanitasi yang memenuhi syarat kesehatan, antara lain klosetnya menggunakan leher angsa atau plengsengan dengan tutup, tempat pembuangan akhir tinjanya menggunakan tanki septik atau Sistem Pengolahan Air Limbah (SPAL), dan fasilitas sanitasi tersebut digunakan oleh rumah tangga sendiri atau bersama dengan rumah tangga lain tertentu (Sirusa BPS).

Provinsi Lampung merupakan provinsi yang memiliki "rapor buruk" dalam hal akses air minum dan sanitasi layak. Hal ini didasari dari data Badan Pusat Statistik pada tahun 2018, akses air minum layak untuk Provinsi Lampung sebesar 56,78 persen. Dalam hal air minum layak, Provinsi Lampung hanya unggul dari tetangganya yaitu Provinsi Bengkulu yang berada diposisi terbawah dengan persentase 49,37 persen. Sedangkan untuk akses sanitasi layak, Provinsi Lampung juga berada pada posisi 4 terendah di Indonesia dengan persentase 52,48 persen. Akses Sanitasi di Provinsi Lampung hanya unggul dari 4 Provinsi Lainnya, yaitu Papua (33,75 \%), Bengkulu $(44,31 \%)$ dan Nusa Tenggara Timur (50,72\%).

Rendahnya akses air minum dan sanitasi layak di Provinsi Lampung disebabkan masih minimnya infrastruktur air minum dan sanitasi layak di Provinsi tersebut. Kondisi geografis yang sulit dijangkau juga menjadi kendala pembangunan infrastruktur. Kemudian adanya ketimpangan dan kesenjangan antar Kabupaten/Kota di Provinsi Lampung juga mengakibatkan rendahnya akses air minum dan sanitasi layak. Di Daerah Perkotaan, yaitu di Kota Bandar Lampung dan Kota Metro, akses air minum layak cukup tinggi, masing masing sebesar 83,80 persen dan 79,48 persen. Kedua Kota tersebut memiliki akses air minum layak tertinggi di Provinsi Lampung. Sementara itu, Kabupaten yang memiliki akses air minum layak terendah adalah Kabupaten Lampung utara dan Kabupaten Way kanan yaitu sebesar 22,19 persen dan 27,93 persen. Dengan demikian, dapat disimpulkan bahwa akses air minum layak di Kota Bandar Lampung dan Metro hampir empat kali lebih bagus dibandingkan dengan akses air minum di Kabupaten Lampung utara dan Way Kanan. Fenomena ini perlu mendapat perhatian khusus karena berdasarkan rata-rata persentase rumah tangga dengan akses terhadap air minum layak untuk wilayah Indonesia Bagian Barat telah mencapai 73,45 persen pada tahun 2018. Dengan demikian, Kondisi tersebut menggambarkan ketimpangan yang terjadi antarKabupaten/Kota di Provinsi Lampung.

Sementara itu, untuk sanitasi layak di Kabupaten/Kota Provinsi Lampung juga masih terdapat ketimpangan. Terdapat tujuh Kabupaten yang memiliki persentase dibawah 50 persen untuk rumah tangga yang tempat akhir tinjanya menggunakan tangki septik atau sistem pengolahan air limbah (SPAL). Ketujuh Kabupaten tersebut adalah Kabupaten Lampung barat, Lampung timur, Lampung Tengah, Lampung Utara, Way kanan, Mesuji dan Tulang Bawang Barat. Sedangkan untuk penggunaan kloset dengan leher angsa, terdapat sembilan Kabupaten yang persentase rumah tangga penggunaan jenis kloset leher angsa kurang dari 90 persen. Di Kabupaten Mesuji, persentase rumah tangga yang menggunakan jenis kloset berupa leher angsa sebesar 64,82 persen. Sedangkan di Kota Bandar Lampung dan Kota Metro hampir seluruh rumah tangga menggunakan kloset leher angsa, dengan persentase masing-masing 98,52 persen dan 99,57 persen.

Melihat adanya kesenjangan dan ketimpangan seperti hal diatas, diperlukan pengkajian mendalam terkait indikatro akses air minum dan sanitasi layak di Provinsi Lampung untuk mendorong tercapainya target 100 persen akses universal air minum dan sanitasi. Dengan demikian, dapat ditelusuri kelompok Kabupaten/Kota mana yang perlu diperhatikan guna mendorong dan mempercepat target tersebut. Penelitian ini bertujuan untuk menganalisis kondisi air minum dan sanitasi layak di Provinsi Lampung dan menganalisis daerah mana yang perlu dipercepat untuk 
program agenda daerah $100 \%$ akses universal air minum dan sanitasi layak. Oleh karena itu, sangat penting memerhatikan pengelompokkan 15 Kabupaten/Kota di Provinsi Lampung berdasarkan indikator akses air minum dan sanitasi layak Tahun 2018.

Dalam penelitian ini akan dilakukan Analisis cluster untuk mengelompokkan Kabupaten/Kota di Provinsi Lampung menjadi beberapa kelompok pengamatan. Metode yang digunakan pada analisis cluster adalah metode Hierarki.

\section{METODE}

\section{Data dan Variabel Penelitian}

Data dalam penelitian ini adalah data sekunder yang berasal dari Publikasi Indikator Perumahan dan kesehatan Lingkungan 2018, Statistik Kesejahteraan Rakyat Provinsi Lampung Tahun 2018. Unit observasi adalah 15 Kabupaten/Kota di Provinsi Lampung pada tahun 2018. Terdapat 7 variabel untuk analisis clustering akses air minum dan sanitasi layak Kabupaten/Kota di Provinsi Lampung, ketujuh variabel tersebut adalah sebagai berikut:

Tabel 1. Variabel penelitian

\begin{tabular}{|c|c|}
\hline Variabel & Penjelasan Variabel \\
\hline (1) & $(2)$ \\
\hline $\mathbf{X}_{\mathbf{1}}$ & $\begin{array}{l}\text { Persentase rumah tangga yang menggunakan sumber air minum bersih adalah persentase } \\
\text { rumah tangga yang menggunakan sumber air minum bersih yang terdiri dari air kemasan, } \\
\text { air isi ulang, leding, dan sumur bor/pompa, sumur terlindung serta mata air terlindung } \\
\text { dengan jarak ke tempat penampungan limbah/kotoran/tinja terdekat lebih dari } 10 \text { meter. }\end{array}$ \\
\hline $\mathbf{X}_{\mathbf{2}}$ & $\begin{array}{l}\text { Persentase rumah tangga yang menggunakan sumber air minum layak adalah persentase } \\
\text { rumah tangga yang menggunakan air minum layak (berkualitas) untuk minum. Air minum } \\
\text { layak (berkualitas) adalah air minum yang terlindung meliputi air ledeng (keran), keran } \\
\text { umum, hydrant umum, terminal air, penampungan air hujan (PAH) atau mata air dan sumur } \\
\text { terlindung, sumur bor atau sumur pompa, yang jaraknya minimal } 10 \text { meter dari pembungan } \\
\text { kotoran, penampungan limbah dan pembuangan sampah. Tidak termasuk air kemasan, air } \\
\text { dari penjual keliling, air yang dijual melalui tangki, air sumur dan mata air tidak terlindung. }\end{array}$ \\
\hline $\mathbf{X}_{3}$ & $\begin{array}{l}\text { Persentase rumah tangga yang menggunakan akses air minum layak adalah perbandingan } \\
\text { antara rumah tangga dengan akses terhadap sumber air minum berkualitas (layak) dengan } \\
\text { rumah tangga seluruhnya yang dinyatakan dalam persentase. }\end{array}$ \\
\hline $\mathbf{X}_{4}$ & Persentase rumah tangga yang memiiliki fasilitas buang air besar digunakan sendiri \\
\hline $\mathbf{X}_{\mathbf{5}}$ & $\begin{array}{l}\text { Persentase rumah tangga yang memiliki jenis kloset yang digunakan adalah leher angsa. } \\
\text { Kloset leher angsa adalah kloset yang dibawah dudukannya terdapat saluran berbentuk huruf } \\
\text { "U" (seperti leher angsa) }\end{array}$ \\
\hline$X_{6}$ & $\begin{array}{l}\text { Persentase rumah tangga yang tempat pembungan akhir tinja adalah tangki septik/IPAL. } \\
\text { Tangki septik adalah tempat pembuangan akhir yang berupa bak penampungan, biasanya } \\
\text { terbuat dari pasangan bata/batu atau beton di semua sisinya juga bagian dasarnya. } \\
\text { Sedangkan IPAL adalah sebuah struktur yang dirancang untuk membuang limbah biologis } \\
\text { dan kimiawi dari air sehingga memungkinkan air tersebut untuk digunakan pada aktivitas } \\
\text { yang lain. }\end{array}$ \\
\hline $\mathbf{X}_{\mathbf{7}}$ & $\begin{array}{l}\text { Persentase rumah tangga yang menggunakan sumber air layak utama untuk memasak/mandi } \\
\text { dan cuci }\end{array}$ \\
\hline
\end{tabular}

Menurut Strategi pencapaian target dan indikator (SDGs), Tujuan keenam pada program pembangunan berkelanjutan atau Suistanable Development Goals (SDGs) memiliki 4 strategi dengan tiga indikator. Ketiga indikator tersebut adalah:

a. Proporsi rumah tangga yang memiliki akses air minum layak. Pada indikator ini digunakan 3 variabel yaitu sumber air minum bersih, sumber air minum layak dan akses air minum layak.

b. Proporsi rumah tangga yang memiliki akses sanitasi layak. Pada indikator ini digunakan 3 variabel yaitu presentase fasilitas buang air besar yang digunakan sendiri, jenis kloset yang digunakan adalah leher angsa dan penggunaan tangki septik/IPAL dalam tempat pembuangan akhir tinja. 
C. Persentase total sumber air yang digunakan. Data ini tidak tersedia, sehingga digunakan pendekatan dengan variabel persentase rumah tangga yang menggunakan sumber air layak untuk memasak/mandi dan cuci.

\section{Metode Hierarchical Cluster}

Metode yang digunakan dalam penelitian ini adalah analisis cluster (analisis gerombol). Analisis klaster adalah tehnik yang digunakan untuk mengklasifikasikan objek ke dalam kelompok yang relatif homogen yang disebut cluster. Objek dalam tiap cluster cenderung memiliki kemiripan satu dengan lainnya, sedangkan antar cluster mempunyai sifat yang berbeda. Analisis cluster juga disebut analisis klasifikasi atau taksonomi numeric (numerical taxonomy). Analisis cluster pada prinsipnya digunakan untuk mereduksi data yaitu meringkas sejumlah variabel menjadi lebih sedikit dan menamakannya sebagai cluster.

Analisis cluster dapat dibagi menjadi dua jenis, yaitu Hierarchical Cluster dan K-Means Cluster (Nonhierarchical cluster). Pengelompokkan secara hierarki biasanya digunakan untuk jumlah sampel yang relatif sedikit. Sedangkan untuk data yang banyak dapat digunakan K-Means Cluster.

Tujuan pengklasteran ialah untuk mengelompokkan obyek yang mirip dalam klaster yang sama, maka beberapa ukuran diperlukan untuk mengakses seberapa mirip atau berbeda obyek-obyek tersebut. Pendekatan yang paling biasa ialah mengukur kemiripan dinyatakan dalam jarak (distance) antara pasangan obyek. Makin besar nilai ukuran kemiripan atau jarak antar dua buah obyek, makin besar pula perbedaan antara dua objek tersebut, sehingga cenderung untuk tidak menganggapnya ke dalam kelompok yang sama.

Terdapat beberapa cara dalam mengukur jarak, yaitu:

a. Menggunakan jarak euclidean, yaitu jarak berupa akar kuadrat perbedaan nilai untuk tiap variabel.

$$
\begin{aligned}
& \text { Jika } x=\left(x_{1}, x_{2}, \ldots, x_{p}\right) \\
& Y=\left(y_{1}, y_{2}, \ldots, y_{p}\right) \text { maka } \\
& D(x, y)=\sqrt{(x 1-y 1)^{2}+(x 2-y 2)^{2} \ldots+(x p-y p)^{2}}
\end{aligned}
$$

b. Menggunakan jarak kuadrat euclidean (squared euclidean distance).

c. The city Block or Manhattan Distance antara dua objek merupakan jumlah nilai perbedaan mutlak untuk tiap variabel. Jarak ini juga disebut jarak Minkowski.

Jika $x^{\prime}=\left(x_{1}, x_{2}, \ldots, x_{p}\right) ; p$ adalah variabel. Maka $x_{1}^{\prime}=\left(x_{i 1}, x_{i 2}, \ldots, x_{i p}\right)$ adalah kumpulan variabel pada obyek ke-i $\mathrm{d}_{\mathrm{ij}}=\left(\sum_{k=1}^{p} x_{i k}-y_{i k}\right)^{1 / r}$

dengan $\mathrm{d}_{\mathrm{ij}}$ adalah jarak antar dua obyek ke-I dan obyek ke-j

Langkah-langkah yang dilakukan dalam pengklasteran:

1. Sampel yang diambil harus benar-benar bisa mewakili populasi.

2. Pengujian Multikolinieritas untuk mengetahui ada tidaknya variabel independen yang memiliki kemiripan dengan variabel independen lainnya.

3. Transformasi data

Jika terdapat perbedaan nilai yang besar antar variabel yang dapat menyebabkan bias dalam analisis klaster maka data asli perlu ditransformasikan (standarisasi). Misalnya terdapat variabel dalam satuan puluhan dan ada dengan satuan ratusan. Perbedaan data yang besar akan menyebabkan perhitungan jarak menjadi tidak valid.

4. Analisis Klaster 
Metode yang digunakan adalah metode hierarki (average Linkage) dengan teknik agglomerative dan ukuran jarak euclidean. Langkah-langkah pengelompokkan dalam analisis klaster dengan metode hierarki mencakup tiga hal, yaitu:

a. Mengukur kesamaan jarak Hal yang penting dalam penggerombolan adalah bagaimana mengkualifikasi ukuran kemiripan antar obyek.

b. Membentuk klaster secara hierarkis

Dalam metode ini menggunakan aglomerasi. Dalam metode aglomerasi tiap observasi pada mulanya dianggap sebagai cluster tersendiri sehingga terdapat cluster sebanyak jumlah observasi. Kemudian dua cluster yang terdekat kesamaannya digabung menjadi suatu cluster baru, sehingga jumlah cluster berkurang satu pada tiap tahap.

c. Melakukan interpretasi terhadap klaster yang terbentuk

Tahap akhir dari analisis klaster adalah menginterpretasikan dari klaster-klaster yang terbentuk.

\section{HASIL DAN PEMBAHASAN}

\section{Analisis Deskriptif}

Capaian akses air minum dan sanitasi layak di Provinsi Lampung telah mengalami perkembangan positif. Hal ini dikarenakan selama tiga tahun terakhir mengalami peningkatan, baik pada akses air minum maupun sanitasi layak. Namun demikian, capaian akses air minum dan sanitasi layak untuk daerah perkotaan lebih tinggi dibandingkan dengan daerah perdesaan.

\section{Capaian akses air minum layak}

Pada tahun 2018, capaian akses air minum layak untuk Provinsi Lampung sebesar 56,78 persen sedangkan secara Nasional angkanya sebesar 73,68 persen. Capaian Provinsi Lampung tersebut merupakan posisi terbawah kedua setelah Provinsi Bengkulu yang berada diposisi terbawah yaitu 49,37 persen. Capaian akses air minum untuk daerah perkotaan di Provinsi Lampung cenderung lebih besar dibandingkan daerah perdesaan. Pada tahun 2016 sampai dengan 2018, capaian akses air minum layak untuk daerah perkotaan masing-masing sebesar 72,83 persen; 71,20 persen dan 72,08 persen. Sementara untuk daerah perdesaan, capaian akses air minum layak masih sangat minim. Pada tahun 2016 dan 2017, capaian masih kurang dari 50 persen, yaitu sebesar 45,56 persen pada tahun 2016 dan 47,71 persen pada tahun 2017. Sedangkan untuk tahun 2018, capaian akses air minum layak mencapai 50,85 persen. Rendahnya akses air minum layak di Provinsi Lampung dikarenakan rendahnya angka akses air minum di masing-masing Kabupaten Provinsi Lampung.

Tabel 2. Persentase rumah tangga di Daerah Perkotaan dan Perdesaan yang memiliki Akses terhadap Air Minum Layak di Provinsi Lampung dan Indonesia Tahun 2016-2018

\begin{tabular}{ccccccc}
\hline & \multicolumn{3}{c}{ Lampung } & \multicolumn{3}{c}{ Nasional } \\
\cline { 2 - 6 } Tahun & Perkotaan & Perdesaan & Perkotaan/Perdesaan & Perkotaan & Perdesaan & Perkotaan/Perdesaan \\
& & & & & & \\
$\mathbf{2 0 1 6}$ & 72,83 & 45,56 & 52,41 & 81,05 & 60,72 & 71,14 \\
$\mathbf{2 0 1 7}$ & 71,2 & 47,71 & 53,79 & 80,82 & 62,1 & 72,04 \\
\hline $\mathbf{2 0 1 8}$ & 72,08 & 50,85 & 56,78 & 81,55 & 64,18 & 73,68 \\
\hline
\end{tabular}

Sumber : Indikator Perumahan dan Kesehatan Lingkungan 2018 


\section{Capaian akses sanitasi layak}

Pada tahun 2018, capaian akses sanitasi layak untuk Provinsi Lampung sebesar 52,48 persen sedangkan secara Nasional angkanya sebesar 69,27 persen. Capaian Provinsi Lampung tersebut merupakan posisi keempat terbawah setelah Provinsi Papua, Bengkulu dan Nusa Tenggara Timur. Capaian akses sanitasi layak untuk daerah perkotaan di Provinsi Lampung lebih tinggi dibandingkan daerah Perdesaan. Pada tahun 2016 sampai dengan 2018, capaian akses sanitasi layak untuk daerah perkotaan masing-masing sebesar 85,17 persen, 80,43 persen dan 76,55 persen. Sementara untuk daerah perdesaan, capaian akses sanitasi layak pada tahun 2016 sampai dengan 2018 masingmasing sebesar 49,66 persen, 43,28 persen dan 43,16 persen.

Rendahnya akses sanitasi layak di Provinsi Lampung diakibatkan oleh rendahnya akses sanitasi pada komponen penggunaan tangki septik pada pembuangan akhir tinjanya. Hanya terdapat 56 rumah tangga dari 100 rumah tangga di Provinsi Lampung yang menggunakan tangki septik atau IPAL pada pembuangan akhir tinjanya.

Tabel 3. Persentase rumah tangga di Daerah Perkotaan dan Perdesaan yang memiliki Akses Sanitasi Layak di Provinsi Lampung dan Indonesia Tahun 2016-2018

\begin{tabular}{ccccccc}
\hline & \multicolumn{3}{c}{ Lampung } & \multicolumn{3}{c}{ Nasional } \\
\cline { 2 - 6 } Tahun & Perkotaan & Perdesaan & Perkotaan/Perdesaan & Perkotaan & Perdesaan & Perkotaan/Perdesaan \\
& & & 58,58 & 80,77 & 54,16 & 67,80 \\
$\mathbf{2 0 1 6}$ & 85,17 & 49,66 & 52,89 & 80,67 & 53,43 & 67,89 \\
\hline $\mathbf{2 0 1 7}$ & 80,43 & 43,28 & 52,48 & 80,48 & 55,74 & 69,27 \\
\hline $\mathbf{2 0 1 8}$ & 76,55 & 43,16 & & & & \\
\hline
\end{tabular}

Sumber : Indikator Perumahan dan Kesehatan Lingkungan 2018

\section{Perbandingan Akses air minum dan sanitasi layak Kabupaten/Kota di Provinsi Lampung}

Akses air minum dan sanitasi layak di Provinsi Lampung cenderung mengalami ketimpangan dan kesenjangan terutama untuk daerah Kota dan Kabupaten. Berdasarkan tabel 3 dibawah ini, daerah Perkotaan yaitu Kota Bandar Lampung dan Kota Metro memiliki akses air minum dan sanitasi layak yang cukup tinggi. Akses air minum layak di Kota Bandar Lampung dan Metro masing-masing sebesar 83,80 persen dan 79,48 persen. Sementara itu, akses air minum layak di daerah Kabupaten berada dibawah angka Daerah Kota. Kabupaten Lampung Utara, Way kanan dan Tulang Bawang Barat merupakan tiga kabupaten dengan akses air minum layak terbawah di Provinsi Lampung yaitu masing-masing sebesar 22,19 persen; 27,93 persen dan 35,92 persen. Sedangkan Kabupaten Pringsewu merupakan pengunci untuk daerah Kabupaten yang memiliki akses air minum layak terbaik. Kabupaten yang pernah mendeklarasikan Open Defecation Free (ODF) dan Gerakan Masyarakat Hidup Sehat (Germas) ini memiliki akses air minum layak sebesar 79,47 persen. Kemudian disusul oleh Kabupaten Tulang Bawang, Lampung Selatan dan Tanggamus dengan masing-masing sebesar 69,98 persen; 67,37 persen dan 65,83 persen.

Sementara itu, untuk akses sanitasi layak di Daerah Kota juga sangat tinggi jika dibandingkan daerah Kabupaten di Provinsi Lampung. Kota Metro merupakan Kota dengan akses sanitasi layak tertinggi di Provinsi Lampung, yaitu sebesar 96,77 persen. Hal ini menunjukkan bahwa terdapat 97 dari 100 rumah tangga yang memiliki akses sanitasi layak. Tingginya akses sanitasi layak di Kota Metro disebabkan tingginya penggunaan pada kloset jenis leher angsa yang hampir mencapai angka 100 persen. Sementara itu, Kota Bandar Lampung merupakan Kota tertinggi kedua dalam hal akses sanitasi layak yaitu sebesar 86,41 persen.

Sedangkan untuk Kabupaten Lampung Barat, Tulang Bawang Barat dan Way Kanan merupakan tiga Kabupaten yang memiliki akses sanitasi terendah yaitu masing-masing sebesar 25,46 persen; 
26,08 persen dan 26,13 persen. Kabupaten Lampung Selatan merupakan Kabupaten dengan akses sanitasi terbaik yaitu sebesar 78,26 persen.

Tabel 3. Perbandingan Akses Air minum dan sanitasi layak Kabupaten/Kota di Provinsi Lampung Tahun 2018

\section{Kabupaten/Kota}

Akses Air Minum Layak

Sanitasi Layak

\begin{tabular}{|lcc|}
\hline \multicolumn{1}{c}{$(\mathbf{1})$} & $(2)$ & $(3)$ \\
\hline Lampung Barat & 62,32 & 25,46 \\
\hline Tanggamus & 65,83 & 48,50 \\
\hline Lampung Selatan & 67,37 & $\mathbf{7 8 , 2 6}$ \\
\hline Lampung Timur & 43,33 & 33,36 \\
\hline Lampung Tengah & 50,97 & 43,10 \\
\hline Lampung Utara & 22,19 & 27,27 \\
\hline Way Kanan & 27,93 & 26,13 \\
\hline Tulang Bawang & 69,98 & 63,87 \\
\hline Pesawaran & 61,30 & 65,39 \\
\hline Pringsewu & 79,47 & 74,16 \\
\hline Mesuji & 60,03 & 33,58 \\
\hline Tulang Bawang Barat & 35,92 & 26,08 \\
\hline Pesisir Barat & 51,15 & 51,86 \\
\hline Bandar Lampung & 83,80 & 86,41 \\
\hline Metro & 79,48 & 96,77 \\
\hline Provinsi Lampung & $\mathbf{5 6 , 7 8}$ & $\mathbf{5 2 , 4 8}$ \\
\hline
\end{tabular}

\section{Analisis Hierarchical Cluster}

Untuk mengetahui jarak dari kemiripan antar Kabupaten/Kota di Provinsi Lampung dapat dilihat pada tabel Proximity Matrix berikut ini:

Tabel 4. Proximity Matrik Hasil Output SPSS

\begin{tabular}{|c|c|c|c|c|c|c|c|c|c|c|c|c|c|c|c|}
\hline Case & \multicolumn{15}{|c|}{ Squared Euclidean Distance } \\
\hline & Lambar & Tgms & Lamsel & \begin{tabular}{|l} 
Lamti \\
m
\end{tabular} & $\begin{array}{l}\text { Lamten } \\
\mathrm{g}\end{array}$ & Lamut & Wayknan & Tuba & Peswrn & Pringswu & Mesuji & tbb & Pesisir & Balam & Metro \\
\hline Lambar & ,000 & ,436 & 3,953 & 4,981 & 2,680 & 9,107 & 4,837 & 1,092 & 672 & 3,708 & ,293 & 3,383 & 151 & 8,939 & 6,692 \\
\hline Tgms &, 436 & ,000 & 4,998 & 7,759 & 4,630 & 13,248 & 8,149 & 1,796 & 1,135 & 4,195 & 754 & 6,172 & 994 & 9,967 & 7,001 \\
\hline Lamsel & 3,953 & 4,998 & ,000 & 2,056 & 1,056 & 6,180 & 5,607 & 893 & 1,436 & 178 & 6,320 & 3,934 & 2,908 & 1,044 & 734 \\
\hline Lamtim & 4,981 & 7,759 & 2,056 & ,000 & ,427 & 1,128 & 1,271 & 2,574 & 3,358 & 3,332 & 6,672 & 811 & 3,399 & 4,316 & 5,006 \\
\hline Lamteng & 2,680 & 4,630 & 1,056 & ,427 & ,000 & 2,758 & 1,812 & 911 & 1,389 & 1,799 & 4,193 & 913 & 1,573 & 3,683 & 3,552 \\
\hline Lamut & 9,107 & 13,248 & 6,180 & 1,128 & 2,758 & ,000 & 1,045 & 6,784 & 7,843 & 8,323 & 10,493 & 1,478 & 7,003 & 8,968 & 10,601 \\
\hline Wayknan & 4,837 & 8,149 & 5,607 & 1,271 & 1,812 & 1,045 & ,000 & 4,422 & 4,921 & 7,206 & 5,375 & , 180 & 3,500 & $\begin{array}{r}10,02 \\
7\end{array}$ & 10,378 \\
\hline Tuba & 1,092 & 1,796 & 893 & 2,574 & 911 & 6,784 & 4,422 & ,000 & ,076 & ,837 & 2,486 & 2,819 & ,635 & 3,788 & 2,523 \\
\hline Peswrn & 672 & 1,135 & 1,436 & 3,358 & 1,389 & 7,843 & 4,921 & ,076 & ,000 & 1,223 & 1,850 & 3,235 & 424 & 4,747 & 3,131 \\
\hline Pringswu & 3,708 & 4,195 & 178 & 3,332 & 1,799 & 8,323 & 7,206 & ,837 & 1,223 & , 000 & 6,081 & 5,200 & 2,927 & 1,230 & ,454 \\
\hline Mesuji & ,293 & 754 & 6,320 & 6,672 & 4,193 & 10,493 & 5,375 & 2,486 & 1,850 & 6,081 &, 000 & 4,100 & 686 & $\begin{array}{r}12,41 \\
1\end{array}$ & 9,784 \\
\hline tbb & 3,383 & 6,172 & 3,934 & 811 & ,913 & 1,478 & 180 & 2,819 & 3,235 & 5,200 & 4,100 & , 000 & 2,220 & 8,034 & 8,066 \\
\hline Pesisir & 151 & 994 & 2,908 & 3,399 & 1,573 & 7,003 & 3,500 & ,635 & ,424 & 2,927 & 686 & 2,220 & ,000 & 7,420 & 5,684 \\
\hline Bandar_L & 8,939 & 9,967 & 1,044 & 4,316 & 3,683 & 8,968 & 10,027 & 3,788 & 4,747 & 1,230 & 12,411 & 8,034 & 7,420 & ,000 & ,434 \\
\hline Metro & 6,692 & 7,001 & 734 & 5,006 & 3,552 & 10,601 & 10,378 & 2,523 & 3,131 & ,454 & 9,784 & 8,066 & 5,684 & ,434 & ,000 \\
\hline
\end{tabular}

Tabel di atas menunjukkan matriks jarak antara variabel satu dengan variabel lain. Semakin kecil jarak Squared euclidean, maka semakin mirip kedua variabel tersebut sehingga akan 
membentuk kelompok (cluster). Dari Tabel 4 dia atas, jarak yang terdekat adalah antara Kabupaten Lampung Barat dan Pesisir Barat, yaitu sebesar 0,151. Dengan demikian dapat disimpulkan bahwa terdapat kemiripan yang sangat erat antara kedua Kabupaten tersebut. Jarak terdekat kedua adalah Kabupaten Pringsewu dengan Kabupaten Lampung Selatan yaitu sebesar 0,178. Keempat Kabupaten tersebut merupakan Kabupaten yang saling berdekatan dan satu sama lain adalah induk Kabupaten sebelum terjadi pemecahan (Kabupaten Pesisir Barat merupakan pecahan dari Kabupaten Lampung Barat pada tahun 2015, dan Kabupaten Pringsewu merupakan pecahan dari Kabupaten Lampung selatan).

Berdasarkan hasil analisis kluster menurut 7 variabel diatas, 15 Kabupaten/kota di Provinsi Lampung dikelompokkan berdasarkan karakteristik yang sama. Dari gambar dendogram dibawah ini, dapat diputuskan berapa banyak cluster yang akan dibentuk. Dari gambar tersebut, sebaiknya dibuat tiga cluster. Tiga cluster tersebut diharapkan mampu menggambarkan perbedaan karakteristik satu cluster dengan cluster lainnya.

Berdasarkan dendogram dibawah ini, dari 15 Kabupaten/Kota di Provinsi Lampung dapat dikelompokkan menjadi tiga cluster. Ketiga cluster tersebut adalah sebagai berikut:

1. Cluster 1 terdiri dari Kota Bandar Lampung, Kota Metro, Kabupaten Lampung Selatan dan Pringsewu.

2. Cluster 2 terdiri dari Lampung Utara, Lampung Tengah, Lampung Timur, Tulang Bawang Barat, Way Kanan.

3. Cluster 3 terdiri dari Kabupaten Tanggamus, Mesuji, Pesisir Barat, Lampung Barat, Pesawaran dan Tulang Bawang.

Berdasarkan hasil clustering tersebut, maka pencirian klaster dari masing-masing cluster tersebut adalah sebagai berikut:

Tabel 5. Data rata-rata akses air minum dan sanitasi layak Kabupaten/Kota di Provinsi Lampung Berdasarkan Tiga Cluster yang dibentuk

\begin{tabular}{|c|c|c|c|c|c|c|c|c|}
\hline $\begin{array}{l}\text { No } \\
\text { Cluste } \\
\text { r }\end{array}$ & $\begin{array}{c}\text { Kabupaten/Kot } \\
\text { a }\end{array}$ & $\begin{array}{l}\text { Sumbe } \\
\text { r air } \\
\text { minum } \\
\text { bersih } \\
\left(X_{1}\right)\end{array}$ & $\begin{array}{c}\text { Sumbe } \\
\text { r air } \\
\text { minum } \\
\text { layak } \\
\left(X_{2}\right)\end{array}$ & $\begin{array}{c}\text { akses } \\
\text { air } \\
\text { minu } \\
\text { m } \\
\text { layak } \\
\left(X_{3}\right)\end{array}$ & $\begin{array}{l}\text { fasilitas } \\
\text { buang air } \\
\text { besar } \\
\text { digunakan } \\
\text { sendiri } \\
\left(X_{4}\right)\end{array}$ & $\begin{array}{c}\text { Jenis } \\
\text { kloset } \\
\text { yang } \\
\text { diguankan } \\
\text { adalah } \\
\text { leher } \\
\text { angsa }\left(X_{5}\right)\end{array}$ & $\begin{array}{c}\text { Penggu } \\
\text { naan } \\
\text { tangki } \\
\text { septik } \\
\left(\mathrm{X}_{6}\right)\end{array}$ & $\begin{array}{l}\text { sumber air } \\
\text { utama } \\
\text { untuk } \\
\text { memasak/ } \\
\text { mandi dan } \\
\text { cuci }\left(X_{7}\right)\end{array}$ \\
\hline \multirow[t]{4}{*}{1} & Bandar Lampung & \multirow{4}{*}{$\begin{array}{l}79,84 \\
(T)\end{array}$} & \multirow{4}{*}{$\begin{array}{l}36,53 \\
(S)\end{array}$} & \multirow{4}{*}{$\begin{array}{l}77,53 \\
(T)\end{array}$} & \multirow{4}{*}{$\begin{array}{c}88,52 \\
(T)\end{array}$} & \multirow{4}{*}{$\begin{array}{l}96,26 \\
(T)\end{array}$} & \multirow{4}{*}{$\begin{array}{l}88,32 \\
(T)\end{array}$} & \multirow{4}{*}{$\begin{array}{l}87,47 \\
(T)\end{array}$} \\
\hline & Metro & & & & & & & \\
\hline & Pringsewu & & & & & & & \\
\hline & Lampung Selatan & & & & & & & \\
\hline \multirow[t]{5}{*}{2} & Way Kanan & \multirow{5}{*}{$\begin{array}{c}36,39 \\
(R)\end{array}$} & \multirow{5}{*}{$\begin{array}{c}29,34 \\
(R)\end{array}$} & \multirow{5}{*}{$\begin{array}{l}36,07 \\
(R)\end{array}$} & \multirow{5}{*}{$\begin{array}{l}87,37 \\
(S)\end{array}$} & \multirow{5}{*}{$\begin{array}{c}81,33 \\
(R)\end{array}$} & \multirow{5}{*}{$\begin{array}{c}32,61 \\
(R)\end{array}$} & \multirow{5}{*}{$\begin{array}{l}43,40 \\
(R)\end{array}$} \\
\hline & $\begin{array}{l}\text { Tulang Bawang } \\
\text { Barat }\end{array}$ & & & & & & & \\
\hline & Lampung Timur & & & & & & & \\
\hline & Lampung Tengah & & & & & & & \\
\hline & Lampung Utara & & & & & & & \\
\hline \multirow[t]{6}{*}{3} & Tulang Bawang & \multirow{6}{*}{$\begin{array}{l}64,09 \\
(S)\end{array}$} & \multirow{6}{*}{$\begin{array}{l}44,26 \\
(T)\end{array}$} & \multirow{6}{*}{$\begin{array}{l}61,77 \\
(S)\end{array}$} & \multirow{6}{*}{$\begin{array}{c}79,45 \\
(R)\end{array}$} & \multirow{6}{*}{$\begin{array}{l}82,69 \\
(S)\end{array}$} & \multirow{6}{*}{$\begin{array}{l}56,67 \\
(S)\end{array}$} & \multirow{6}{*}{$\begin{array}{c}73,06 \\
(S)\end{array}$} \\
\hline & Pesawaran & & & & & & & \\
\hline & lampung barat & & & & & & & \\
\hline & Pesisir Barat & & & & & & & \\
\hline & Mesuji & & & & & & & \\
\hline & Tanggamus & & & & & & & \\
\hline
\end{tabular}


Pencirian cluster dilakukan dengan membandingkan nilai antar cluster dalam suatu variabel. Perbandingan tersebut menggunakan tiga skala, yaitu tinggi, sedang dan rendah. Adapun pencirian dari ketiga cluster tersebut adalah sebagai berikut:

1. Cluster pertama yang terdiri dari Kota Bandar Lampung, Metro, Kabupaten Pringsewu dan Lampung Selatan merupakan cluster dengan rata-rata akses air minum dan sanitasi layak tertinggi dibandingkan cluster lainnya. Pada cluster ini, dari tujuh variabel terdapat enam variabel merupakan nilai tertinggi dibandingkan cluster lainnya. Untuk variabel penggunaan leher angsa pada jenis kloset yang digunakan $\left(X_{5}\right)$ merupakan variabel dengan nilai tertinggi yaitu 96,26 persen. Kemudian variabel fasilitas buang air besar yang digunakan sendiri sebesar 88,52 persen dan sumber air utama untuk memasak/mandi dan cuci merupakan air layak sebesar 87,47 persen. Sementara sumber air minum bersih dan akses minum layak sebesar 79,84 persen dan 77,53 persen. Hanya variabel sumber air minum layak yang berkategori sedang yaitu sebesar 36,53 persen. Pada cluster pertama ini, meskipun merupakan kelompok tertinggi dari berbagai variabel pendukung akses air minum dan sanitasi layak, namun masih perlu adanya peningkatan akses air dan sanitasi layak menuju Lampung 100 \% universal akses air minum dan sanitasi.

2. Cluster kedua yang terdiri dari 5 Kabupaten merupakan cluster dengan nilai rata-rata akses air minum dan sanitasi layak terendah dibandingkan dengan cluster pertama dan ketiga.. Hanya variabel fasilitas buang air besar yang digunakan sendiri yang memiliki persentase lebih tinggi dibandingkan cluster kedua, yaitu sebesar 87,37 persen. Sedangkan enam variabel lainnya merupakan variabel dengan rata-rata terendah, khususnya untuk variabel $X_{1}, X_{3}, X_{6}$, dan $X_{7}$ dengan nilai rata-rata masing-masing sebesar 36,39 persen; 36,07 persen; 32,61 persen dan 43,40 persen. Pada cluster ini, diperlukan pemusatan untuk peningkatan pada seluruh variabel penelitian untuk meningkatkan angka secara keseluruhan di Provinsi Lampung. Mengingat tiga diantara anggota cluster ini yaitu Lampung Timur, Lampung Tengah dan Lampung Utara merupakan Kabupaten besar yang memiliki penyumbang besar untuk angka di Provinsi Lampung. Peningkatan akses air minum dan sanitasi layak dapat dilakukan dengan membuat penyaluran air minum ke daerah yang kurang sumber air dan dibangunnya Sistem penyediaan air minum (SPAM) yang masif dan terintegrasi. Kebijakan lainnya dapat juga berupa larangan buang air besar sembarangan (BABS) maupun pembuatan kloset/WC untuk masyarakat, selain itu perlu diadakan sosialisasi bagi masyarakat untuk membuat sumber air minum (dapat berupa sumur) yang jaraknya lebih dari 10 meter dari tempat pembuangan akhir tinja.

3. Cluster ketiga merupakan cluster dengan nilai rata-rata sedang atau berada dipertengahan dibandingkan dengan cluster pertama dan kedua. Pada cluster ini, variabel $X_{1}, X_{3}, X_{5}, X_{6}$ dan $X_{7}$ berada pada posisi pertengahan dengan kategori sedang, nilai rata-rata variabel tersebut masingmasing sebesar 64,09 persen; 61,77 persen; 82,69 persen; 56,67 persen dan 73,06 persen. Meskipun cluster ini merupakan kelompok pertengahan, namun masih perlu adanya peningkatan yang masif dalam penanganan air minum dan sanitasi layak. Penanganan tersebut dapat berupa aturan untuk masyarakat agar mengubah perilaku higienis dan sanitasi layak.

\section{KESIMPULAN}

Kesimpulan dari panelitian ini adalah permasalahan air minum dan sanitasi layak di Provinsi Lampung masih menjadi tugas berat bagi seluruh stakeholder. Keterbatasan regulasi, anggaran dan kelembagaan serta kesadaran dari masyarakat Lampung untuk menggerakkan program air minum dan sanitasi layak menjadi faktor utama belum tercapainya target universal akses.

Terjadi ketimpangan dan kesenjangan akses air minum dan sanitasi layak untuk daerah perkotaan dan perdesaan. Selain itu, ketimpangan dan kesenjangan juga terjadi di 15 Kabupaten/Kota yang berada di Provinsi Lampung. 15 Kabupaten/Kota tersebut dikelompokkan 
menjadi tiga cluster/kelompok dengan kriteria akses air minum dan sanitasi yang tinggi, sedang dan rendah.

\section{DAFTAR PUSTAKA}

Verania Andria (2015). Indicators And Data Mapping To Measure Sustainable Development Goals (SDGs) Targets: Case of Indonesia 2015. Jakarta. United Nations Development Programme.

Badan Pusat Statistik (2018). Indikator Perumahan dan Kesehatan Lingkungan 2018. Badan Pusat Statistik.Jakarta.

Badan Pusat Statistik (2018), Indikator Kesejahteraan Rakyat: Hunian Layak masyarakat berpenghasilan rendah. Badan Pusat Statistik. Jakarta

Brodjonegoro, Bambang (2015). Roadmap of SDGs Indonesia: a Highlight. Ministry of National Development Planning/National Development Planning Agency. Jakarta.

Ben Satriatna (2015). Menyongsong SGDs Kesiapan Kabupaten/Kota di Provinsi Lampung. Lampung. Unpad Press.

Santoso, Singgih (2010). Statistik Multivariat :Konsep dan Aplikasi dengan SPSS. Jakarta. PT Elex Media Komputindo.

Basri F.H. 1995. Perekonomian Indonesia Menjelang Abad XXI : Distorsi, Peluang dan Kendala. Jakarta:Erlangga.

Awaliah, R (2018). Analisis Clustering untuk mengelompokkan tingkat kesejahteraan Kabupaten/Kota berdasarkan Sosial Ekonomi Rumah Tangga di Wilayah Provinsi Sulawesi Selatan. Universitas Islam Negeri (UIN) Alauddin Makassar.

Soemartini dan Enny Supartini (2017), Analisis K-Means Cluster untuk Pengelompokkan Kabupaten/Kota di Jawa Barat Berdasarkan Indikator Masyarakat, Konferensi Nasional Penelitian Matematika dan Pembelajarannya II (KNPMP II). Universitas Muhammadiyah Surakarta. 18 Maret 2018 